\title{
Peningkatan pembelajaran keterampilan berbicara melalui media gambar seri di kelas I
}

\author{
Zarlianti \\ SDN 08 Painan Kecamatan IV Jurai Pesisir Selatan
}

Article Info:

Accepted 1Juli 2019

Published Online 27 Juli 2019

\begin{abstract}
The goal is that students are brave, accustomed to being able to speak in all functions according to proper pronunciation and intonation Data collection is carried out by tests, observations or observation sheets and other supporting instruments of research. This study uses a qualitative approach with a type of classroom action research. The research subjects were first grade students of SDN. 08 Painan District IV Jurai. Based on the results of the study, the serial image media can improve students' speaking skills with three-stage learning activities, namely: (1) initial activities, (2) core activities, and (3) final activities. The result of the first cycle of research based on the implementation of the lesson plan is $76.8 \%$ and the recapitulation of student learning assessment is 74\%. The results of the second cycle research based on the implementation of lesson plans were $83.9 \%$ and the recapitulation of the assessment process and student learning outcomes was $83 \%$. From the results of observations and recapitulation of values obtained by students, it appears that students are active in the learning process.
\end{abstract}

Keywords: speaking skills, series image media

CC This is an open access article distributed under the Creative Commons Attribution License, which permits unrestricted use, distribution, and reproduction in any medium, provided the original work is properly cited. (C2019 by author

\section{PENDAHULUAN}

Keterampilan berbicara merupakan bidang pembelajaran yang sangat penting di samping keterampilan berbahasa yang lainnya, karena keterampilan berbicara siswa juga sangat mempengaruhi penilaian belajar siswa. Dalam lingkungan pendidikan, siswa dituntut terampil berbicara selama dalam proses pembelajaran. Siswa harus mampu mengutarakan gagasan, menjawab pertanyaan, mengajukan pertanyaan dengan baik sehingga siswa yang lain mengerti apa yang dimaksud dari pertanyaannya.

Berdasarkan observasi yang telah peneliti lakukan pada siswa Kelas Ic SDN 08 Painan Kecamatan IV Jurai, terungkap bahwa siswa belum terampil berbicara (kurang lancar, merasa malu dan takut), ternyata pembelajaran keterampilan berbicara yang selama ini dilakukan hanya sebatas bertanya jawab dengan siswa dan meminta beberapa orang siswa untuk bercerita di depan kelas. Akibatnya tidak semua siswa berani untuk berbicara di depan kelas.

Hal ini disebabkan kurangnya kreatifitas guru dalam merancang dan menyajikan pembelajaran. Dapat di lihat pada penggunaan media yang tidak ada sama sekali, hingga berimbas pada hasil belajar siswa yang tidak mencapai target sesuai dengan tujuan dari pembelajaran bahasa Indonesia seperti yang diamanatkan dalam kurikulum.

Dari uraian di atas, peneliti tertarik untuk melakukan suatu penelitian tindakan kelas dengan judul "Peningkatan pembelajaran keterampilan berbicara melalui media gambar seri di Kelas Ic SDN 08 Painan Kecamatan IV Jurai Kabupaten Pesisir Selatan”. 


\section{METODE}

Data penelitian ini berupa hasil pengamatan, wawancara, catatan lapangan dan dokumentasi. Dari setiap tindakan perbaikan pembelajaran berbicara melalui media gambar seri di Kelas Ic SDN 08 Painan Kecamatan IV Jurai. Data penelitian ini adalah menggunakan pencatatan lapangan, observasi, wawancara, dan hasil tes catatan lapangan pada dasarnya berisi deskripsi atau paparan tentang latar pengamatan terhadap tindakan praktek sewaktu pembelajaran berbicara melalui media gambar seri itu juga membuat rancangan refleksi berdasarkan pengamatan yang dilakukan peneliti dengan observasi yang dilakukan. Sumber data penelitian ini adalah proses kegiatan pembelajaran keterampilan berbicara melalui media gambar seri untuk meningkatkan keterampilan berbicara siswa yang meliputi: (1) rancangan RPP, (2) pelaksaan proses pembelajaran, (3) pengamatan proses pembelajaran, (4) penilaian pembelajaran, dan (5) prilaku peneliti serta siswa sewaktu kegiatan proses pembelajaran. Data diperoleh dari subjek terteliti, yaitu peneliti dan siswa Kelas Ic SDN 08 Painan Kecamatan IV Jurai Kabupaten Pesisir Selatan.

\section{HASIL}

\section{Hasil Penelitian Siklus I}

1. Perencanaan

Perencanan tindakan pada siklus I disusun berdasarkan hasil studi pendahuluan yang telah peneliti lakukan pada hari Senin, 25 Maretl 2019 pukul 09.00 WIB di SDN 08 Painan Kecamatan IV Jurai Kabupaten Pesisir Selatan.

Berdasarkan hasil pengamatan diperoleh gambaran sebagai berikut: (1) pembelajaran keterampilan berbicara yang dilakukan tidak mengkondisikan siswa sesuai dengan tujuan, (2) informasi mengenai proses pembelajaran berbicara kurang disosialisasikan kepada siswa, (3) kurangnya informasi membuat siswa tidak siap dalam mengikuti proses pembelajaran keterampilan berbicara, (4) pelaksanaan pembelajaran keterampilan berbicara tidak menggunakan media pembelajaran yang disesuaikan dengan materi yang diberikan, dan (5) penilaian pembelajaran keterampilan berbicara tidak dilakukan pada proses dan hasil dari pembelajaran keterampilan berbicara.

Melalui hasil studi pendahuluan tersebut disusun perencanaan tindakan pada Semester II Tahun ajaran 2018/2019. Penyusunan perencanaan tindakan didiskusikan teman sejawat. Hasil diskusi tersebut dimanisfestasikan dalam bentuk seperangkat RPP.

2. Pelaksanaan

Pelaksanaan proses pembelajaran pertemuan pertama pada siklus I dalam meningkatkan keterampilan berbicara melalui media gambar seri pada pembelajaran bahasa Indonesia di Kelas Ic SDN 08 Painan Kecamatan IV Jurai Kabupaten Pesisir Selatan dilaksanakan pada hari Senin, tanggal 08 April 2019 pukul 08.00-09.00 WIB. Proses pembelajaran keterampilan berbicara melalui media gambar seri dibagi menjadi tiga, yaitu kegiatan awal, kegiatan inti, kegiatan akhir.

Kegiatan awal proses pembelajaran di fokuskan pada kegiatan membuka pelajaran berupa penyampaian tujuan pembelajaran dan tugas-tugas yang akan dilaksanakan oleh siswa, menyanyikan lagu sesuai tema yaitu lagu "pada hari minggu", bertanya jawab tentang tempat-tempat yang pernah di kunjungi siswa, memajangkan media gambar seri. Selanjutnya guru menugaskan siswa mengamati gambar seri dan melakukan tanya jawab tentang tempat-tempat yang pernah dikunjunginya seperti tempat-tempat wisata, kerumah kerabat dan lain-lain. Kegiatan selanjutnya adalah bertanya jawab tentang peristiwa-peristiwa yang terdapat disetiap gambar seri.

Kegiatan inti pada proses pembelajaran di awali dengan kegiatan bertanya jawab tentang gambar seri yang telah dipajang oleh guru didepan kelas. Kemudian guru menugaskan siswa untuk mengamati media gambar seri. Setelah semua siswa mengamati gambar seri yang dipajang di depan kelas, kemudian guru menugaskan siswa untuk saling menceritakan antar teman sebangku.

Kegiatan meminta tanggapan siswa tentang media gambar yang telah di ceritakan dengan bahasa sendiri dengan menggunakan lafal, intonasi dan ekspresi yang sesuai berlangsung secara baik. Hal ini terwujud saat siswa memberikan tanggapan tentang isi cerita. Penilaian dilakukan saat siswa memberikan 
tanggapan tentang isi cerita berdasarkan alasan yang logis dan sesuai dengan isi cerita. Kegiatan ini berlangsung selama lebih kurang tiga puluh menit. Kegiatan akhir proses pembelajaran keterampilan berbicara yang dilakukan pada pertemuan ini adalah menyampaikan pesan-pesan moral dan membimbing siswa menyimpulkan pembelajaran serta motivasi siswa untuk lebih meningkatkan keterampilan berbicara.

3. Pengamatan

Pengamatan keberhasilan tindakan proses pembelajaran diamati selama dan sesudah tindakan dilaksanakan. Kegiatan ini dilakukan oleh observer yang terdiri dari Teman sejawat SDN 08 Painan Kecamatan IV Jurai Kabupaten Pesisir Selatan ibu Sefrinel Dewita sebagai rekan sejawat.

a. Aktivitas guru dalam kegiatan pembelajaran

Hasil observasi yang dilakukan pengamat I terhadap peneliti (praktisi) dapat dilihat pada tabel berikut:

Proses pembelajaran berbicara melalui media gambar seri yang terselenggara sudah sesuai dengan RPP, perolehan skor 43:56 (skor maksimal) x 100\% dengan persentase 76,8\%. Disini terlihat guru cukup berhasil dalam melaksanakan proses pembelajaran. Hanya saja guru agak kedodoran dalam masalah waktu. Hal ini terjadi pada masing-masing kegiatan proses pembelajaran. Kelebihan waktu tersebut berkisar antara lima belas sampai dua puluh menit untuk masing-masing kegiatan proses pembelajaran. Namun guru senang dengan penelitian ini, karena setiap siswa sudah mulai berani bercerita ke depan kelas secara khusus dan lebih berani dalam berbicara secara umum.

Selain itu dalam pelaksanaan pembelajaran ini peneliti juga terkendala karena keributan siswanya sebanyak 25 orang siswa, Peneliti dalam proses pembelajaran keterampilan berbicara melalui media gambar seri harus berulang kali menenangkan siswa terlebih dahulu sebelum melanjutkan kembali pelajaran. Karena siswa Kelas I SD adalah siswa peralihan dari taman kanak-kanak maka kegiatan pembelajaran yang berlangsung haruslah menyenangkan. Peneliti sebagai guru dalam penelitian ini mensiasatinya dengan selingan bernyanyi di saat siswa sudah mulai tidak fokus dengan kegiatan pembelajaran, adapun lagu yang dinyanyikan haruslah lagu yang dikenal dan disenangi oleh siswa.

b. Aktivitas siswa dalam kegiatan pembelajaran

Sementara pencapaian keberhasilan siswa pada siklus I berdasarkan rambu-rambu yang telah diisi oleh ovserver yaitu 78,6\%. Dengan perolehan skor 44:56 (skor maksimal) x 100\%. Keberhasilan ini berada dalam taraf baik.

Pada kegiatan inti, kemampuan siswa cukup baik di mana dengan bantuan media pembelajaran hampir sebahagian siswa saling berebut untuk tampil kedepan melihat, menunjuk, dan menceritakan media gambar seri meski tidak semua siswa mencerikan media gambar seri sabahagian siswa hanya menyebutkan point-point dari media gambar seri dan bahkan ada beberapa siswa hanya diam ketika sudah berada di depan kelas. Untuk mengatasi hal tersebut peneliti menuntun siswa dengan mengajukan pertanyaan-pertanyaan yang berkaitan dengan media gambar seri.

Pada kegiatan akhir siswa untuk mendengarkan pesan-pesan moral dan menyimpulkan pembelajaran. Pada saat menyimpulkan pembelajaran siswa kurang aktif dan hanya beberapa siswa yang bisa mengulang kembali simpulan yang telah sebutkan sebelumnya.

Rujukan terhadap taraf keberhasilan ketuntasan tindakan penelitian pada siklus I ini berpatokan pada standar ketuntasan BNSP (2006:12). Tabel rujukan standar ketuntasan belajar tersebut adalah sebagai berikut:

Tabel 3: Taraf keberhasilan ketuntasan penelitian

\begin{tabular}{lll}
\hline Taraf Keberhasilan & Sebutan & Ketuntasan \\
\hline $\mathbf{8 8}-\mathbf{1 0 0 \%}$ & & Tuntas \\
$\mathbf{7 5}-\mathbf{8 7 \%}$ & Baik sekali & Tuntas \\
$\mathbf{6 3}-\mathbf{7 4 \%}$ & Baik & Belum Tuntas \\
\hline$<\mathbf{6 2 \%}$ & Cukup & Belum Tundas \\
\hline
\end{tabular}


c. Penilaian dalam proses peningkatan pembelajaran keterampilan berbicara melalui media gambar seri

Penilaian proses keterampilan berbicara siswa melalui media gambar seri pada siklus I ini lebih dirinci berdasarkan rata-rata sebagai berikut yaitu: (1) keranian 3,4\%, (2) kelancaran 2,9\%, (3) kesesuaian isi cerita dengan gambar 2,7\%, (4) lafal dan intonasi $2,7 \%$. Keberhasilan ini berada pada taraf cukup.

Dari keseluruhan penilaian proses tersebut dapat di uraikan bahwa dua siswa mendapatkan kualifikasi sangat baik (jumlah nilai 16), delapan belas siswa mendapat kualifikasi baik (jumlah nilai 12-13), enam siswa mendapat kualifikasi cukup (jumlah nilai 10-11), empat siswa mendapat kualifikasi kurang (jumlah nilai 6-9). Dengan persentase masing-masing aspek yaitu keberanian 3,4:4 (aspek yang dinilai) $\mathrm{x} 100 \%=$ $85 \%$, kelancaran 2,9:4 (aspek yang dinilai) x 100\% $=72 \%$, kesesuaian isi cerita dengan gambar 2,7:4 (aspek yang dinilai) x 100\% =67\%, lafal dan intonasi 2,7:4 (aspek yang dinilai) $x 100 \%=67 \%$. Memperoleh rata-rata kelas yaitu: 11,8 dengan persentase nilai $73,8 \%$. Contoh: siswa RY jumlah skor yang diperoleh pada penilaian proses yaitu: 9:16(skor max) x 100\% $=56 \%$, maka siswa RY mendapat kualifikasi kurang.

Data-data tersebut memberi gambaran bahwa dari empat aspek yang dinilai ada dua aspek yang memperoleh nilai kurang yaitu aspek kesesuaian isi cerita dengan gambar dan aspek lafal/intonasi. Bila ditinjau dari aspek kesesuaian isi cerita dengan gambar maka disebabkan oleh karena siswa Kelas I Sekolah Dasar memiliki keterbatasan perbendaharaan kosa kata sehingga siswa mengalami kesulitan dalam mengembangkan konsep-konsep yang telah dimilikinya tentang gambar yang ada di depan kelas menjadi sebuah cerita sederhana. Keterbatasan kosa kata siswa tersebut membuat isi cerita siswa banyak yang tidak sesuai dengan media gambar seri.

Penilaian hasil pada proses pembelajaran keterampilan berbicara melalui media gambar seri meliputi kemampuan menjawab pertanyaaan, kelancaran membaca karangan, kerapian tulisan, dan penggunaan tanda baca. Penilaian hasil pembelajaran berbicara pada siklus I ini lebih dirinci berdasarkan rata-rata sebagai berikut: (1) mampu menjawab pertanyaan 3,2\%, (2) kelancaran membaca karangan 3,0\%, (3) kerapian tulisan $2,9 \%$, (4) penggunaan tanda baca $2,7 \%$.

Dari keseluruhan penilaian hasil tersebut dapat di uraikan bahwa tiga siswa mendapatkan kualifikasi sangat baik (jumlah nilai 16), delapan belas siswa mendapat kualifikasi baik (jumlah nilai 12-14), tiga siswa mendapat kualifikasi cukup (jumlah nilai 10-11), enam siswa mendapat kualifikasi kurang (jumlah nilai 7-9).

Contoh: siswa RS jumlah skor yang diperoleh pada penilaian hasil adalah 11:16 (skor max) $\mathrm{x} 100 \%=$ 69\%, maka siswa RS mendapat kualifikasi cukup.

Dengan persentase masing-masing aspek yaitu: mampu menjawab pertanyaan 3,2:4 (aspek yang dinilai) $\times 100 \%=80 \%$, kelancaran membaca karangan 3,0:4 (aspek yang dinilai) $\times 100 \%=75 \%$, kerapian tulisan 2,9:4 (aspek yang dinilai) x 100\% =72\%, penggunaan tanda baca 2,7:4 (aspek yang dinilai) x $100 \%$ $=67 \%$. Memperoleh rata-rata kelas yaitu: 11,9 dengan persentase nilai 74,3\% (C).

Data-data tersebut memberi gambaran bahwa dari empat aspek yang dinilai ada satu aspek yang memperoleh nilai kurang yaitu aspek penggunaan tanda baca. Hal ini wajar karena siswa Kelas I Sekolah Dasar belum tahu banyak tentang pengunaan tanda baca yang tepat dan benar. Oleh sebab itu penilaian pengunaan tanda baca disini juga disesuaikan dengan kemampuan siswa yaitu hanya mencakup pengunaan tanda titik, koma, tanda tanya dan tanda seru.

Penilaian yang menyeluruh terhadap kegiatan proses pembelajaran berbicara melalui media gambar seri ini meliputi penilaian proses dan penilaian hasil. Penilaian tersebut lebih dirinci berdasarkan rata-rata sebagai berikut: (1) penilaian proses 11,8\%, dan (2) penilaian hasil 11,9\%. Dari rekapitulasi penilaian proses dan penilaian hasil tersebut dapat di uraikan masing-masing persentasenya sebagai berikut: penilaian proses 11,8:16 (nilai $\max$ ) x $100 \%=73 \%$, penilaian hasil 11,9:16 (nilai $\max$ ) x $100 \%=74 \%$, memperoleh rata-rata kelas yaitu: 11,9 dengan persentase nilai $74 \%(\mathrm{C})$.

Data-data tersebut memberi gambaran bahwa dari empat aspek yang dinilai ada satu aspek yang memperoleh nilai kurang yaitu aspek keberhasilan siswa dalam mengikuti seluruh kegiatan proses pembelajaran berbicara melalui media gambar seri pada siklus I adalah 11,9\%.

Rumus ketuntasan perorangan: 
$\mathrm{P}=\frac{f}{N} \times 100$

Rumus ketuntasan belajar:

$\mathrm{P}=\frac{f}{N} \times 100$

Dari data diatas, dapat di peroleh gambaran bahwa hasil pembelajaran berbicara melalui media gambar seri adalah sebagai berikut: nilai tertinggi pada siklus I adalah 16 dan nilai terendah adalah 7,5. Dari data rekapitulasi penilian proses dan penilaian hasil persentase ketuntasan yang diperoleh adalah $53,3 \%$ dan yang tidak tuntas adalah $46,7 \%$ dengan 16 orang siswa yang tuntas dan 14 orang siswa yang tidak tuntas. Berdasarkan data tersebut dapat disimpulkan bahwa pembelajaran pada siklus I tidak mencapai ketuntasan yang diinginkan sesuai dengan tuntutan sesuai dengan BNSP 2006 yaitu $75 \%$.

4. Refleksi

Pada kegiatan proses pembelajaran, hasil pengamatan yang dilakukan guru kelas selaku pengamat I terhadap peneliti, langkah-langkah yang dilakukan peneliti sudah sesuai dengan perencanaan. Hasil pengamatan sudah mencapai hasil cukup baik. Guru sudah melakukan langkah-langkah pembelajaran sesuai dengan RPP.

Apabila jawaban siswa tidak sesuai dengan media gambar maka disini guru meminta siswa untuk kembali mengamati media gambar seri yang ada dan guru kembali mengajukan pertanyaan yang sama kepada siswa. Sedangkan kegiatan akhir dilakukan dengan meminta siswa menanggapi cerita yang telah didengar dan penyampaian pesan-pesan moral, dan membimbing siswa menyimpulkan pembelajaran. Reflaksi yang dilakukan pada siklus selanjutnya akan memberikan penekanan kepada siswa agar mampu menceritakan media gambar seri dengan bahasa sendiri dengan lafal dan nintonasi yang sesuai.

\section{Hasil Penelitian Siklus II}

1. Perencanaan

Tindakan pelaksanakan siklus II pada pertemuan pertama dilaksanakan pada hari Senin, tanggal 15 April 2019 pukul 08.00-09.00 WIB. Sementara pertemuan kedua dilaksanakan pada hari Rabu, tanggal 17 April 2019, pukul 08.00-09.00 WIB pada mata pelajaran bahasa Indonesia di Kelas Ic SDN 08 Painan Kecamatan IV Jurai Kabupaten Pesisir Selatan dengan alokasi waktu masing-masing pertemuan 2x30 menit.

2. Pelaksanaan

Pada kegiatan awal proses pembelajaran di fokuskan pada kegiatan membuka pelajaran berupa penyampaian tujuan pembelajaran dan tugas-tugas yang akan dilaksanakan oleh siswa, menyanyikan lagu sesuai tema yaitu lagu "tut-tut-tut ada sepeda", bertanya jawab tentang lagu serta pengalaman yang pernah dialami oleh siswa, memajangkan gambar seri.

Pertanyaan-pertanyaan guru tersebut dapat memotivasi siswa untuk memberikan nomor pada semua gambar seri. Alasan-alasan yang dikemukakan siswa dalam menentukan urutan gambar di arahkan oleh guru dengan mengajukan pertanyaan kembali kepada siswa yang lain hingga siswa yang memilih gambar dengan alasan yang dimilikinya. Apabila urutan dan alasan yang dikemukakan kurang tepat maka guru mengajukan pertanyaan pada siswa yang lain hingga siswa yang mengemukakan alasan, dapat memahami bahwa urutan beserta alasan yang dikemukakan kurang tepat. Hal ini dilakukan hingga semua gambar diberi nomor yang tepat. Proses pembelajaran bertanya jawab dengan siswa dalam memberi nomor urutan pada gambar berlangsung sekitar sepuluh menit.

Kegiatan meminta tanggapan siswa tentang cerita yang telah di ceritakan dengan bahasa sendiri dengan menggunakan lafal dan intonasi yang sesuai berlangsung secara baik. Hal ini terwujud saat siswa memberikan tanggapan tentang isi cerita. Penilaiaan dilakukan saat siswa memberikan jawaban dari pertanyaan yang diajukan dan memberikan tanggapan yang sesuai dengan gambar. Kegiatan ini berlangsung selama lebih kurang lima belas menit. Kegiatan akhir proses pembelajaran keterampilan berbicara yang dilakukan adalah menyampaikan pesan-pesan moral oleh guru dan membimbing siswa menyimpulkan pembelajaran serta motivasi siswa untuk lebih meningkatkan keterampilan berbicara. 
3. Pengamatan

a. Aktivitas guru selama proses pembelajaran

Berdasarkan lembar pengamataan yang diisi oleh pengamat ditemukan informasi dari aspek guru, bahwa guru telah melaksanakan seluruh point-point yang terdapat dalam format pencatatan lapangan dari aspek guru. Perolehan skor yang diperoleh berdasarkan rambu-rambu dari aspek guru adalah proses pembelajaran berbicara melalui media gambar seri adalah 47:56 (skor maksimal) x $100 \%$ dengan persentase $83,9 \%$. Dari persentase skor terlihat guru sudah baik dalam melaksanakan proses pembelajaran.

Proses pembelajaran berbicara melalui media gambar seri yang terselenggara sudah sesuai dengan RPP, hanya saja guru agak kedodoran dalam masalah waktu sama seperti proses pembelajaran pada siklus I. Hal ini terjadi pada masing-masing kegiatan proses pembelajaran. Kelebihan waktu tersebut berkisar antara lima belas sampai dua puluh menit untuk masing-masing kegiatan proses pembelajaran. Walaupun proses pembelajaran yang tertuang dalam RPP sudah dilaksanakan sebaik mungkin oleh guru, namun pada hasil lembar pengamatan dari guru pengamat dan observer terhadap RPP masih berada dalam taraf baik. Sedangkan hasil dari lembaran pengamatan terhadap RPP adalah 93,7\%.

Paparan data pelaksanaan proses pembelajaran berbicara melalui media gambar seri jika ditinjau dari aspek pelaksanaan proses pembelajaran maka terlihat pencapaian keberhasilan guru pada siklus II sebesar 83,9\%. Dengan perolehan skor 47:56 (skor maksimal) x 100\%. Merujuk kepada pencapaian taraf keberhasilan tindakan, keberhasilan guru sebesar $83,9 \%$ ini berada pada taraf baik dan mengalami peningkatan dari siklus I.

b. Aktivitas siswa dalam proses pembelajaran

Dari aspek siswa ditemukan informasi, bahwa siswa sudah melaksanakan seluruh point-point sesuai dengan perencanaan. Siswa terlihat bersemangat dan aktif saat mengikuti proses pembelajaran. Hal ini terlihat dari penilaian rambu-rambu dari aspek siswa dari pencapaiaan keberhasialn siswa sebesar $82,1 \%$. Dengan perolehan skor 46:56 (skor maksimal) x 100\%. Merujuk kepada pencapaian taraf keberhasilan tindakan, keberhasilan guru sebesar $82,1 \%$ ini berada pada taraf baik dan mengalami peningkatan dari siklus I.

c. Penilaian dalam proses peningkatan pembelajara keterampilan berbicara melalui media gambar seri

Data penilaian pada proses pembelajaran keterampilan berbicara melalui media gambar seri terdiri dari penilaian proses dan penilaian hasil. Penilaian proses terdiri dari yaitu aspek keterampilan berbicara yakni: keberaniaan siswa dalam bercerita, kelancaran, kesesuaian isi cerita dengan gambar, dan lafal/intonasi. Penilaian proses keterampilan berbicara siswa pada siklus II ini lebih dirinci berdasarkan rata-rata sebagai berikut yaitu: (1) keranian dalam bercerita 3,7\%, (2) kelancaran dalam bercerita 3,2\%, (3) kesesuaian isi cerita dengan gambar 3,1\%, (4) lafal dan intonasi $3,2 \%$. Keberhasilan siswa dalam proses pembelajaran ini sebesar 13,2\%. Keberhasilan ini berada dalam taraf baik.

Dengan persentase masing-masing aspek yaitu keberanian 3,7:4 (aspek yang dinilai) $\times 100 \%=$ 93\%, kelancaran 3,2:4 (aspek yang dinilai) x 100\% =80\%, kesesuaian isi cerita dengan gambar 3,1:4 (aspek yang dinilai) x 100\% =78\%, lafal dan intonasi 3,2:4 (aspek yang dinilai) x 100\% $=80 \%$. Memperoleh rata-rata kelas yaitu: 13,2 dengan persentase nilai $83 \%$.

Dari uraian penilaian proses dapat diketahui bahwa enam siswa mendapatkan kualifikasi sangat baik (jumlah nilai 15-16), sembilan belas siswa mendapat kualifikasi baik (jumlah nilai 12-14), empat siswa mendapat kualifikasi cukup (jumlah nilai 11), satu siswa mendapat kualifikasi kurang (jumlah nilai 9). Contoh: siswa NA, jumlah skor penilaian proses yang diperoleh yaitu: 14:16 (skor max) $\mathrm{x}$ $100 \%=88 \%$, siswa NA mendapat kulaifikasi baik.

Dari data di atas dapat disimpulkan bahwa skor tertinggi adalah 16 dan nilai terendah adalah 9. Rata-rata kelas 13,2 dengan persentase nilai 82,5\%. Dari nilai yang diperoleh siswa dapat disimpulkan bahwa penilaian proses sudah baik sesuai dengan rujukan penilaian.

Penilaian hasil pada proses pembelajaran berbicara meliputi kemampuan menjawab pertanyaaan, kelancaran membaca karangan, kerapian tulisan, dan penggunaan tanda baca. Penilaian hasil proses pembelajaran berbicara pada siklus I ini lebih dirinci berdasarkan rata-rata sebagai berikut: (1) mampu 
menjawab pertanyaan 3,3\%, (2) kelancaran membaca karangan 3,2\%, (3) kerapian tulisan 2,9\%, (4) penggunaan tanda baca 2,9\%. Keberhasilan siswa pada proses pembelajaran berbicara sebesar $13,1 \%$.

Dengan persentase masing-masing aspek yaitu keberanian 3,7:4 (aspek yang dinilai) $\mathrm{x} 100 \%=$ $93 \%$, kelancaran 3,2:4 (aspek yang dinilai) x 100\% $=80 \%$, kesesuaian isi cerita dengan gambar 3,1:4 (aspek yang dinilai) x 100\% =78\%, lafal dan intonasi 3,2:4 (aspek yang dinilai) $\mathrm{x} 100 \%=80 \%$. Memperoleh rata-rata kelas yaitu: 13,2 dengan persentase nilai 83,\%.

Dari uraian penilaian hasil dapat diketahui bahwa tujuh siswa mendapatkan kualifikasi sangat baik (jumlah nilai 15-16), tujuh belas siswa mendapat kualifikasi baik (jumlah nilai 12-14), empat siswa mendapat kualifikasi cukup (jumlah nilai 10-11), dua siswa mendapat kualifikasi kurang (jumlah nilai 9). Contoh: siswa SS, jumlah skor penilaian hasil yang diperoleh adalah 14:16 (skor max) $\mathrm{x}$ $100 \%=88 \%$, siswa SS mendapat kualifikasi baik.

Dari di atas dapat disimpulkan bahwa nilai tertinggi adalah 16 dan nilai terendah 9, rata-rata kelas 13,1 dengan persentase ketuntasan $81,9 \%$. Sesuai dengan rujukan penilaian dapat disimpulkan bahwa penilaian hasil belajar siswa sudah baik.

Penilaian yang menyeluruh terhadap kegiatan proses pembelajaran berbicara melalui media gambar seri ini meliputi penilaian proses dan penilaian hasil. Penilaian tersebut lebih dirinci berdasarkan rata-rata sebagai berikut: (1) penilaian proses 13,2\%, dan (2) penilaian hasil $13,1 \%$. Keberhasilan siswa dalam mengikuti seluruh kegiatan proses pembelajaran berbicara melalui media gambar seri pada siklus II adalah $13,2 \%$.

Dengan persentase masing-masing aspek yaitu penilaian proses 13,2:16 (nilai max) $\times 100 \%=$ $83 \%$, penilaian hasil 13,1:16 (nilai $\max$ ) x $100 \%=82 \%$. Memperoleh rata-rata kelas yaitu: 13,2 dengan persentase nilai 83,\%. Dari uraian rekapitulasi penilaian dapat diketahui bahwa delapan siswa mendapatkan kualifikasi sangat baik (jumlah nilai 14,5-16), delapan belas siswa mendapat kualifikasi baik (jumlah nilai 12-14), empat siswa mendapat kualifikasi cukup (jumlah nilai 10,5-11,5). keberhasilan ini berada dalam taraf baik dengan uraian sebagai berikut:

Rumus ketuntasan perorangan

$\mathrm{P}=\frac{f}{N} \times 100$

Rumus ketuntasan belajar

$\mathrm{P}=\frac{f}{N} \mathrm{X} 100$

Kriteria keberhasilan menurut BSNP (2006:12) adalah:

$75 \%-100 \%=$ Tuntas

$0 \%-69 \%=$ belum tuntas

Dari data diatas, dapat di peroleh gambaran bahwa hasil pembelajaran berbicara melalui media gambar seri adalah sebagai berikut: nilai tertinggi pada siklus II adalah 16 dan nilai terendah adalah 10,5. Dari data rekapitulasi penilaian proses dan penilaian hasil persentase ketuntasan yang diperoleh adalah $86 \%$ dan yang tidak tuntas adalah $13 \%$ dengan 26 orang siswa yang tuntas dan 4 orang siswa yang tidak tuntas. Berdasarkan data tersebut dapat disimpulkan bahwa pembelajaran pada siklus II mengalami peningkatan jika dibandingkan dari siklus I dan penilaian yang di capai pada siklus II adalah $86 \%$ sudah mencapai ketuntasan. Dimana sudah melebihi ketuntasan yang ditetapkan oleh BNSP 2006 yaitu 75\%..

4. Refleksi

Penilaian berbicara di fokuskan pada penilaian proses dan penilaian hasil. Dimana penilaian proses yaitu: keberanian siswa dalam bercerita, kelancaran dalam bercerita, kesesuaiaan isi cerita dengan gambar, dan lafal dan intonasi. Sementara penilaian hasil yaitu: kemampuan menjawab pertanyaan, kelancaran membaca karangan, kerapian tulisan, penggunaan tanda baca. Saat siswa tampil ke depan kelas untuk bercerita masih ada empat orang siswa yang hanya diam tanpa berbicara. Peneliti sebagai guru berusaha memotivasi siswa dengan mengajukan beberapa pertanyaan yang berkaitan dengan gambar agar siswa tersebut dapat menceritakan gambar dengan bahasa sendiri. 


\section{PEMBAHASAN}

\section{Pembahasan Siklus 1}

1. Bentuk Perencanaan Siklus 1

Pada perencanaan proses pembelajaran diawali dengan kegiatan awal berupa mengkondisikan kelas, menyiapkan sarana dan prasarana untuk proses pembelajaran, dilanjutkan dengan menyampaikan tujuan pembelajaran yaitu agar siswa mampu berbicara melalui media gambar seri. Penyampaian ini sangat penting agar siswa dapat memahami tujuan pembelajaran serta tugas yang akan dilaksanakan nantinya dalam proses pembelajaran. Selajutnya pada kegiatan inti perencanaan pembelajaran diharapkan siswa dapat: (1) menyebutkan peristiwa-peristiwa yang terdapat dalam setiap gambar seri, (2) mengurutkan gambar seri sesuai urutan yang benar, (3) menentukan judul media gambar seri, (4) menceritakan media gambar seri dengan bahasa sendiri. Sedangkan pada kegiatan akhir berupa penyimpulan proses pembelajaran dan pemberian motivasi siswa untuk lebih meningkatkan keterampilan berbicara. Berdasarkan perencanaan yang telah peneliti susun, pelaksanaan proses pembelajaran sudah terselenggara sesuai dengan apa yang telah direncanakan.

2. Pelaksanaan siklus 1

Pelaksanaan proses pembelajaran keterampilan berbicara melalui media gambar seri untuk meningkatkan keterampilan berbicara siswa di Kelas Ic SD terdiri dari kegiatan awal, kegiatan inti, dan kegiatan akhir. Kegiatan awal berupa mempersiapkan situasi, kondisi, sarana dan prasarana untuk proses pembelajaran. Kemudian guru menyampaikan tujuan pembelajaran agar proses pembelajaran menjadi terarah dan sistematis di mana tujuan pembelajaran adalah siswa mampu menceritakan media gambar seri dengan bahasa sendiri. Pelaksanaan pembelajaran yang kreatif dan menyenangkan sangat dibutuhkan oleh siswa di SD terutama pada Kelas Ic karena merupakan peralihan dari taman kanak-kanak di mana masih dalam proses belajar sambil bermain.

Berdasarkan catatan dilapangan dan diskusi peneliti dengan guru kelas serta teman sejawat sebagai kolaborator dan observer, ternyata siswa memiliki kemampuan dalam hal sebagi berikut: (1) menyebutkan peristiwa-peristiwa yang terdapat dalam setiap gambar seri, (2) mengurutkan gambar seri sesuai urutan yang benar, (3) menentukan judul media gambar seri, (4) menceritakan media gambar seri dengan bahasa sendiri. Umumnya kemampuan siswa dalam menceritakan media gambar seri meningkat baik dari segi keberanian dalam bercerita, kelancaran dalam bercerita, kesesuaian isi cerita dengan media gambar seri, maupun penggunaan lafal dan intonasi. penyebabnya munculnya kemampuan dari siswa karena penggunaan media gambar seri yang menarik, dekat dengan kehidupan siswa serta pemberian motivasi yang tiada henti dari guru.

Pembelajaran keterampilan berbicara seperti yang telah peneliti lakukan dalam penelitian ini tidak pernah dilaksanakan oleh guru. Guru tidak pernah menggunakan media khususnya media gambar seri yang dekat dengan kehidupan dan dunia anak-anak dalam proses pembelajaran keterampilan berbicara. Hal ini berdampak pada siswa yang tidak tertarik pada pembelajaran keterampilan berbicara yang diberikan karena bersifat abstrak, sehingga keterampilan berbicara siswa tidak dapat meningkat secara optimal.

\section{Pembahasan Siklus II}

1. Bentuk Perencanaan Siklus I

Indikator yang ingin dicapai pada siklus II ini yaitu: (1) menyebutkan peristiwa-peristiwa yang terdapat dalam setiap gambar seri, (2) mengurutkan gambar seri sesuai urutan yang benar, (3) menentukan judul media gambar seri, dan (4) menceritakan gambar seri dengan bahasa sendiri dengan lafal dan intonasi yang tepat.

2. Pelaksanaan Siklus II

Berdasarkan catatan dilapangan dan diskusi peneliti dengan teman sejawat sebagai kolaborator dan observer, ternyata siswa memiliki kemampuan dalam hal sebagai berikut: (1) menyebutkan peristiwa-peristiwa yang terdapat dalam setiap gambar seri, (2) mengurutkan gambar seri sesuai urutan yang benar, (3) menentukan judul media gambar seri, (4) menceritakan media gambar seri dengan bahasa sendiri. Umumnya kemampuan siswa dalam menceritakan media gambar seri meningkat, baik dari segi keberanian dalam bercerita, kelancaran dalam bercerita, kesesuaian isi cerita dengan media gambar seri, 
maupun penggunaan lafal dan intonasi. Penyebab munculnya kemampuan dari siswa karena penggunaan media gambar seri yang menarik, dekat dengan kehidupan siswa serta pemberian motivasi yang tiada henti dari guru.

3. Penilaian Siklus II

Penilaian dilakukan pada saat siswa berbicara yaitu penilaian proses aspek keterampilan berbicara yang terdiri dari empat point yakni: (1) keranian dalan bercerita, (2) kelancaran dalam bercerita, (3) kesesuaian isi cerita dengan gambar, dan (4) lafal dan intonasi. Sementara penilaian hasil berupa penilaian dari latihan dan tugas-tugas yang telah dikerjakan oleh siswa yang terdiri dari empat point yakni: (1) kemampuan menjawab pertanyaan, (2) kelancaran membaca karangan, (3) kerapian tulisan, dan (4) penggunaan tanda baca. Berdasarkan data-data penilaian proses dan penilaian hasil pada siklus I, nilai rata-rata yang diperoleh siswa adalah $11,9 \%$, dengan empat belas orang siswa yang memiliki jumlah nilai kurang dari 12 dengan persentase ketuntasan 53,3\% sementara target ketuntasan yang ingin dicapai yaitu $75 \%$. Untuk itu hasil refleksi penilaian dari siklus I dilanjutkan ke siklus II, dan hasil penilaian proses dan penilaian hasil dalam keterampilan berbicara melalui medai gambar seri pada siklusII sudah mencapai ketuntasan dengan rata-rata $13,2 \%$, dengan persentase ketuntasan $86 \%$. Dari nilai yang diperoleh pada siklus I dan siklus II mengalami peningkatan. Jadi dapat dikatakan bahwa guru sudah berhasil dalam membelajarkan siswa, dapat dilihat dari hasil penilaiannya. Sebagaimana yang di ungkapkan oleh Mulyasa (2007:259) "penilaian merupakan ukuran untuk mengetahui kemajuan dan hasil belajar siswa, mendiagnosa kesulitan belajar siswa, memberikan umpan balik untuk perbaikan proses pembelajaran, dan penentuan kenaikan kelas". Jadi penilaian terhadap proses dan hasil belajar siswa dapat memberikan gambaran tentang kemampuan masing-masing siswa terhadap proses pembelajaran keterampilan berbicara melalui media gambar seri dengan bahasa sendiri dengan menggunakan lafal dan intonasi yang sesuai.

\section{KESIMPULAN}

Meningkatkan keterampilan berbicara melalui media gambar seri yang telah diselenggarakan pada penelitian ini terbukti sangat efektif dan efesien. Efektifitas tersebut tergambar pada kegiatan sebagai berikut:Meningkatkan keterampilan berbicara dapat dilakukan melalui media gambar seri dengan cara menceritakan media gambar seri dengan bahasa sendiri dengan lafal dan intonasi yang sesuai.Peningkatan keterampilan berbicara siswa juga didukung oleh persiapan perencanaan pelaksanaan pembelajaran berdasarkan kurikulum dan segala komponen-komponen pendukungnya, yang terdiri dari indikator, langkah-langkah pembelajaran, media dan penilaian.Pelaksanaan proses pembelajaran keterampilan berbicara melalui media gambar seri dimulai dari kegiatan awal, kegiatan inti, dan kegiatan akhir. Selama dalam proses pembelajaran keterampilan berbicara melalui media gambar seri guru juga mengajak siswa bernyanyi dengan menyanyikan lagu yang dikenal dan disukai oleh siswa yang bertujuan untuk mengatasi kejenuhan yang dialami oleh siswa.Penilaian dilakukan baik penilaian proses maupun penilaian hasil selama proses pembelajaran keterampilan berbicara melalui media gambar seri berlangsung. Penilaian ini bertujuan agar dapat memberikan gambaran kemampuan masing-masing siswa, mendiagnosa kesulitan belajar yang di alami siswa, memberikan umpan balik untuk perbaikan proses pembelajaran selanjutnya.

\section{DAFTAR RUJUKAN}

Abdul Majid. 2006. Perencanaan Pembelajaran. Bandung: PT. Remaja Rosdakarya.

Ahmad Rohani.1997. Media Intruksional Edukatif. Jakarta: Rineka Cipta.

Alben Ambarita. 2006. Manajemen Pembelajaran. Jakarta: Depdiknas.

Arif Sudiman. 2003. Media Pendidikan. Jakarta: PT. Raja Grafindo Persada.

Arsyad G. Midar dan Mukti U.S. 1991. Pembinaan Kemampuan Berbicara Bahasa Indonesia. Jakarta: Departemen Pendidikan Nasional.

Azhar Arsyad. 2006. Media Pembelajaran. Jakarta: PT.RajaGrafindo Persada.

Basuki, Wibaya. 1991. Media Pengajaran. Jakarta: Departemen Pendidikan dan Kebudayaan Direktorat Jendral Pendidikan Proyek Pembinaan Tenaga Kependidikan.

Dadan Djuanda, 2006. Pembelajaran Bahasa Indonesia yang Komunikatif dan Menyenangkan. Jakarta: Departemen Pendidikan Nasional Direktorat Jendral Pendidikan Tinggi Direktorat Ketenagaan. 
Depdiknas. 2006. Kurikulum Tingkat Satuan Pendidikan Jenjang Pendidikan Dasar. Jakarta: Depertemen Pendidikan Nasional.

Direktorat Jendral Pendidikan Dasar dan Menengah. 2005. Bahasa dan Sastra Indonesia. Jakarta : Depertemen Pendidikan Nasional.

Djago Tarigan. 1997. Pendidikan Bahasa dan Sastra Indonesia di Kelas Rendah. Jakarta: Bumi Aksara.

Farida Rahim.2007. Pengajaran Membaca di Sekolah Dasar. Jakarta: PT. Bumi Aksara.

Hamzah Uno. 2008. Perencanaan Pembelajaran. Jakarta: Bumi Aksara.

Handoko Sudrajat. 2005. Eksplorasi. (online)

Http://id.wikipedia.org/wiki/eksplorasi, diakses 3 Maret 2019.

Harimurti Kridalaksana,. 1996. Kamus Besar Bahasa Indonesia. Jakarta: PT. Balai Pustaka.

Hendri Guntur Tarigan.1998. 